\title{
Strukturális anomáliák talaján kialakult recidív patella ficamok minimál
} invazív ellátása

\author{
DR. VÁSÁRHELYI GÁBOR, DR. KÁRPÁTI ZOLTÁN, \\ DR. SZIGETI ISTVÁN, DR. SZERB IMRE, DUSKA ZSÓFIA, DR. GÁL TAMÁS, \\ DR. HANGODY LÁSZLÓ
}

\section{ÖSSZEFOGLALÁS}

A recidív patella ficamok etiológiájában a lateralis trochlea veleszületett vagy szerzett hypoplasiája fontos szerepet játszik. Sajnálatosan a hazai gyakorlat a mai napig a térdkalács ficamok kezelésében főleg konzervativ, illetve mútét esetén is csak az ezen betegeknél szintén meglévő patológiás húzási irány korrekciójára irányul. A szerzők véleménye szerint, amennyiben a lateralis trochlea, mint patológiai faktor kimutatható, ennek korrekciója is mindenképpen indokolt a húzási irány korrekciójával egy időben. Ismertetik az intézetükben alkalmazott diagnosztikus algoritmust, bemutatják az általuk javasolt, mára már főleg minimál invazív technikával végzett mútét lépéseit, valamint az alkalmazott posztoperatív rehabilitációs protokollt. Saját 10 éves anyagukat összegezve azt a megállapítást teszik, hogy jó kooperációjú betegnél az általuk javasolt mútéti technika jól alkalmazható, és jól vezetett rehabilitációval akár az élsport is elérhető.

\section{Kulcsszavak: $\quad$ Minimál invazív technika; Patellaficam; Térdízület;}

G. Vásárhelyi, Z. Kárpáti, I. Szigeti, I. Szerb, Zs. Duska, T. Gál, L. Hangody: Minimally invasive surgery of recurrent patellar dislocation due to structural anomalies

The congenital or aquired hypoplasia of the lateral trochlea plays an important role in the etiology of recurrent patella dislocations. Unfortunately, in the Hungarian practice, the principal therapy of patella luxations is conservative, or in case of operative treatment, only the abnormal patellar tracking is corrected. The authors suggest that if the pathology of the lateral trochlea is detected, then this too should be by all means treated simultaneously along with the correction of the patellar tracking. This article demonstrates the diagnostic algorythm, presents the steps of the contemporary minimally invasive surgical technique, and the applied postoperative rehabilitation protocol recommended in our department for the treatment of recurrent patella dislocations. Based on the results from the past 10 years, the authors suggest that with the application of the recommended operative technique and rehabilitation on patients with good compliance, even professional athletic activity levels can be reached.

Keywords:

Minimally invasive surgical procedures; Knee joint - Pathology;

Patellar dislocation - Surgery; 


\section{BEVEZETÉS}

A patellofemoralis biomechanika ismerete nélkülözhetetlen a patella ficamok korszerü kezelésében. A legszemléletesebb talán Kapandji hasonlata, miszerint a térd extenzorai a distalis femur részén úgy mozognak, mint csigán a drótkötél. A trochlea, illetve az intercondylaris árok egy mély, függőleges csatornát képez, amiben a patella csúszik, így a quadriceps izomereje distalisan kizárólag függőleges irányú erőként jelenik meg. Normál esetben a patella csak a vertikális síkban mozog, mert a quadriceps izomereje a flexió növekedésével egyre erősebben tartja a helyén. Az extenzió végpontján ez az erő megszúnik, illetve hyperextenzióban meg is fordulhat, vagyis elemelheti a patellát a trochleatól. Ekkor a fiziológás valgus miatt kialakuló lateralis erőkomponens hatására a patella képes oldalra elmozdulni, amit normál esetben az ízületben uralkodó negatív nyomás, a medialis patellofemoralis szalagrendszer, illetve a normálisan magasabb lateralis trochlea szél akadályoz meg (4).

A felismerés, hogy a trochlea anomáliája a distalis extenzor apparátus patológiájában szerepet játszik nem újkeletű, mégis csak a XX. század második felében történtek nagy esetszámot feldolgozó tanulmányok a trochlea szerepéről a patella ficamok etiológiáját illetően. Brattström arra a megállapításra jutott, hogy a patella ficamokon átesett betegeknek szignifikánsan alacsonyabb a lateralis trochlea széle, mint az átlag populációnak. A trochlea alaki eltérése alapján három csoportot különítettek el, ezeket római számokkal jelölték (I., II., III.), mely beosztás a mútéti indikáció felállításánál ma is jól használható. Dejour szerint recurrens patella ficamoknál $85 \%$-ban valamilyen fokú trochlea displasia, mint etiológiai faktor kimutatható. Ők három féle röntgen diagnosztikus jelet - kereszteződési jel, kettős kontúr, sarkantyú - identifikáltak, ezek megléte, vagy hiánya alapján négyféle csoportot különböztettek meg, amelyeket arab betǔvel jelöltek: $A$, $B, C, D(2)$.

A rutinszerűen elvégzett normál kétirányú röntgenen kívül (térd tengely, "Q" szög, Insall-Salvati index, Dejour beosztás) a Merchant technikával elkészített enyhe flexiós összehasonlító betekintő felvételen látható térdkalács-trochlea viszonylatból már konkrét diagnózishoz kell jutnunk (sulcus szög, Brattström klasszifikáció, Wiberg féle patella típusok). A képalkotó diagnosztika fejlődésének, hozzáférhetőségének is köszönhetően mára a viszonylag könnyen elérhető $C T$, illetve $M R$ felvételeknek a diagnosztikus algoritmus részének kell lennie, különös tekintettel a TT-TG távolságnak (tuberositas, illetve trochlea vályú szummációs képen mért távolsága) a mútéti indikáció felállításában játszott szerepére (5).

Hangsúlyozzuk, hogy a trochlea helyreálítását legtöbbször társbeavatkozásként a húzási irány korrekciójával, ventromedializációval, supracondylar femur osteotomiával esetlegesen MPFL pótlással kell elvégezni, amenynyiben szükséges, porcfelszín képzéssel együlésben!

\section{Lateralis troclea kiemelés indikáció}

Alacsony lateralis vagy lapos trochleánál, amelynek oka lehet veleszületett (hypoplasia), illetve rosszul kezelt recurrens ficam kialakulásához vezető korábbi trauma, javasolt elvégezni. Indikációjára már gondolhatunk a 30 fokos patella betekintő felvételen látható rossz patellofemoralis illeszkedésből, amelynek fő oka a sekély trochlea vályú (1. ábra). 


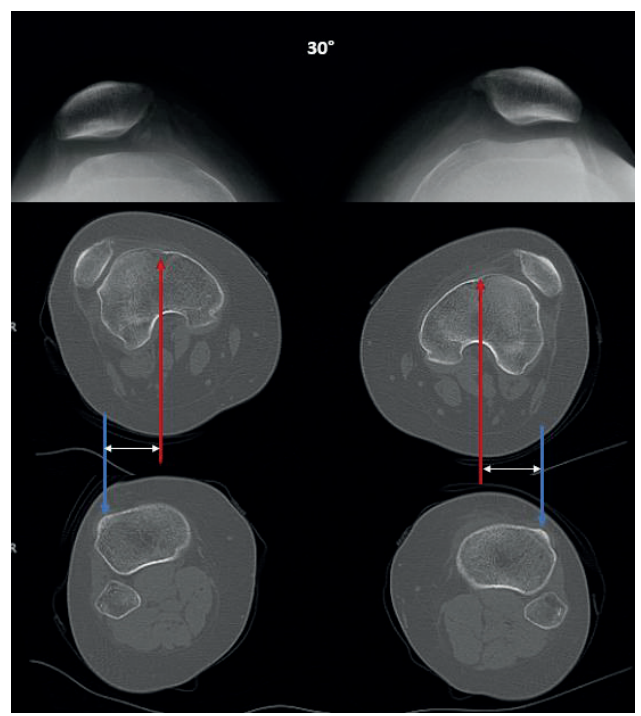

1. ábra

Felsö kép: preoperativ 30 fokos betekintő röntgenfelvételen látszik a hypoplasiás trochlea.

Alsó kép: ugyanezen beteg preoperativ CT képe. Látható az extenzióban mindkét oldalon luxált patella. A piros nyil a trochlea vályút (TG), a kék nyíl a tuberositast (TT), a fehér, a kettő távolságát mutatja (TT-TG).

\section{MÜTÉTI TECHNIKA}

A mútétet hanyatt fekvésben, egyenes lábbal, vértelenségben végezzük. Minimál invazív technikánál oldalra lógatott láb mellett rutin artroszkópos körbetekintést végzünk a típusos portálokon keresztül. Korábban hosszanti egyenes median vagy lateral felé ívelt bőrmetszést, jelenleg lateralis mini arthrotomiát követően lateralis tokmegnyitást, kiterjesztett release-t végzünk, amely során láthatóvá válik a hypoplasiás lateralis condylus szél. Kellő rutint szerezve megpróbálkozhatunk artroszkóposan is elvégezni a lentebb bemutatott lépéseket tartva, lateralis stich incision, illetve kisegítő proximalis portálon keresztül, de a „learning curve” időszaka arthrotomiából történjen! (2. ábra)

Arthrotomiánál az első lépés a tuberositas medializációja, amelyet, ha csak lehet, szintén minimál invazívan végzünk Elmslie-Trillat szerint (1). Artroszkóposan végezve ezt csak a trochlea kiemelést követően javasoljuk az ízületben való könnyebb tájékozódás miatt. A következő lépés, hogy pengevésővel vagy kis oszcillációs fürésszel a terhelő felszín határától proximalisan, körülbelül a porcfelszínnel megegyező vastagságú csontalappal - ez intézetünk saját anyaga alapján még az allogén osteochondralis transzplantációknál is jó porcos túlélést biztosít - alávéssük a lateralis condylust, proximalisan a hypoplasiás porcfelszín fölé 1-2 cm-el (3. ábra).

Ez mindenképpen indokolt, hiszen az ezen beteganyagnál majdnem mindig fennálló magas állású patella így a luxatio szempontjából legkritikusabb mozzanatnál a flexió elején nem tud lateral felé kimozdulni. A kellő magasságot elérve vésővel óvatosan mobilizáljuk a mintegy distal felé „nyelezett” lateralis trochleát (4. ábra).

Nem kell megijedni, ha a terhelő felszín határán repedést észlelünk, de kellő rutinnal, óvatossággal ez elkerülhető. 8,5 mm-es mozaikos graftvevővel az osteotomiától körülbelül 1 cm-rel dorsalisan autológ spongiosát nyerünk (5. ábra).

Ezen spongiosa hengerből nyert körülbelül 3 cm-es spongiosus graft laposfogóval jól modellálható (6. ábra).

Ezt a modellált graftot ezután az elemelt trochleaszél alá ültetjük (7. ábra), végül az osteotomiát proximalisan behelyezett sülylyesztett, kompressziós változó menetemelkedésű csavarral rögzíthetjük, de amennyiben a graft stabil, ettól el is tekinthetünk, hiszen az anesztézia megszúnte után a patellofemoralis feszülés már kellő kompressziót hoz létre. 


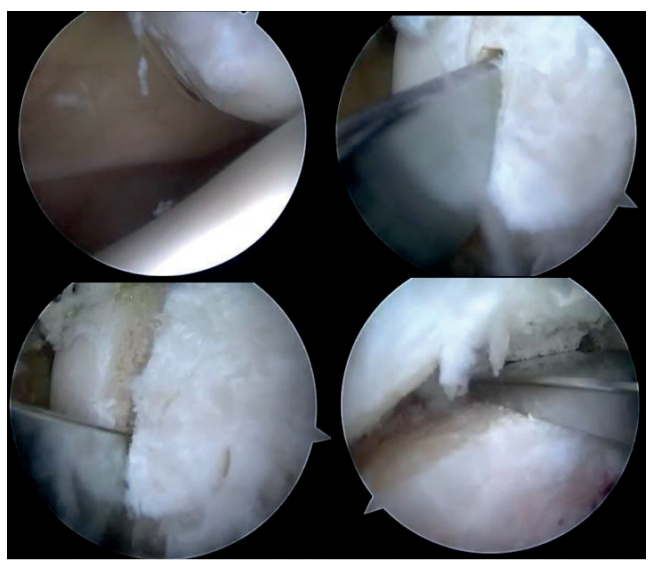

2. ábra

Artroszkópos trochlea kiemelés.

Bal felső kép: lapos trochlea a subluxált térdkaláccsal. Jobb felső, illetve bal alsó kép: subchondralis alávésés pengevésővel fedetten.

Jobb alsó kép: az alávéset trochlea mobilizállása.

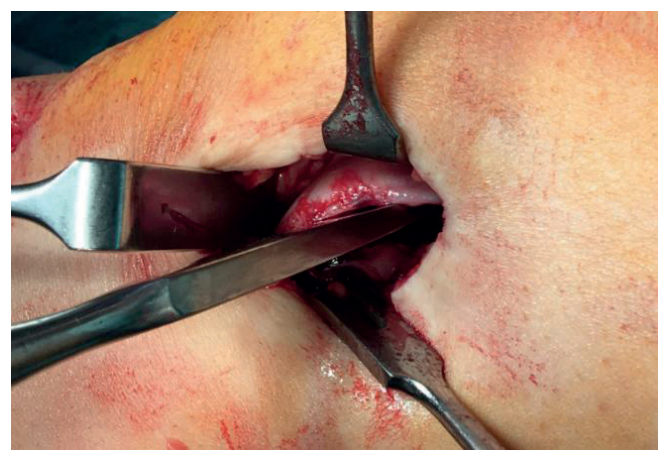

\section{4. ábra}

Az alávésett lateralis trochlea mobilizálása.

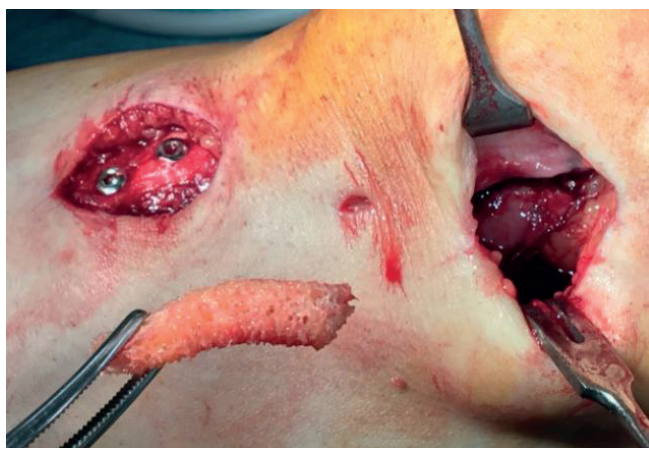

6. ábra

Az eltávolított ASP hengert laposfogóval modelláljuk.

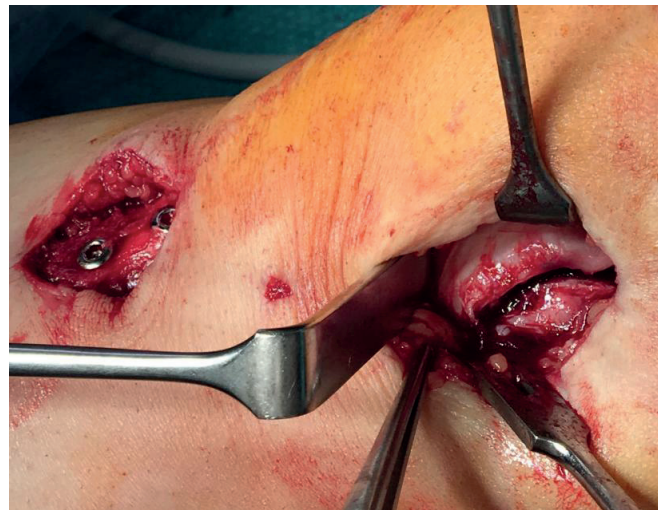

\section{3. ábra}

Lateralis trochlea alávésése mini arthrotomiából. Látható a szintén minimál invazívan elvégzett Elmslie-Trillat tuberositas transzpozíció.

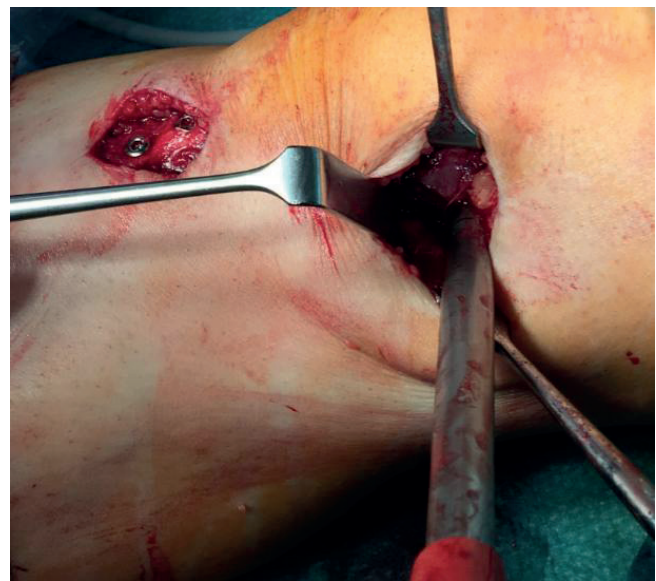

\section{5. ábra}

Az osteotomiától dorsalisan 8,5 mm-es mozaikplasztikás graftvevővel kb. $3 \mathrm{~cm}$-es ASP hengert nyerünk.

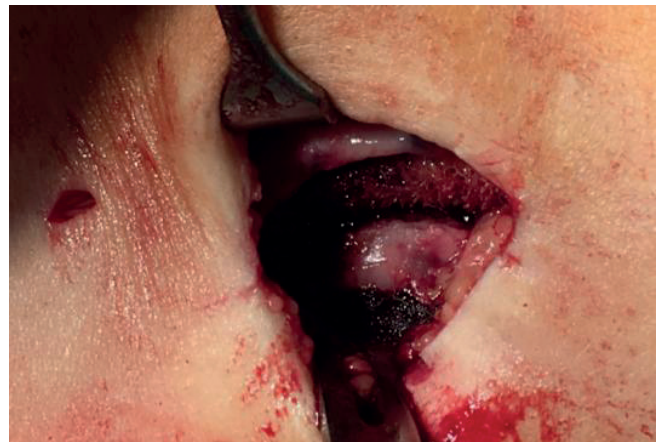

7. ábra

A modellált ASP graftot az elemelt lateralis trochleaszél alá impaktáljuk. 


\section{REHABILITÁCIÓ}

Hangsúlyozzuk a modern elveket szem előtt tartó, a beteghez adaptált fájdalomcsillapítás mellett mihamarabbi aktív mozgatás megkezdésének fontosságát. Közvetlen posztoperatív szakban CPM, cryoterápia, per os NSAID-t követően beindult aktív quadricepsszel 2., 3 . posztoperatív napon emittálunk. A relatíve rövid tehermentesítést követően 2-4 hét után gyakorlatilag a teljes terhelést megengedjük. Flexiót 3 hétig 60 fokig, 4 hétig 90 fokig engedjük, 4 hetes kortól intenzív, gyógytornász vezetésével végzett heti háromszori tornát rendelünk. Sport tevékenység megkezdése 3-6 hónaptól várható.

\section{EREDMÉNYEK}

2008-2018 között 31 esetben végeztünk trochlea kiemelést. 15 esetben már valamiféle primer beavatkozást követően. 2 esetet leszámítva nőkön végeztük, 17-45 koreloszlásban, 5 alkalommal kétoldalon. Két esetben már korábban történt tuberositas medializációt követően, a többi esetben Emslie-Trillat mútéttel együlésben végeztük. Az osztályos bennfekvés átlagosan 3 nap volt, varratszedés posztoperatív 10-14. napon, a teljes terhelés megkezdése 4 hetesen engedtük még úgy is, hogy a betegek nagy részénél tuberositas áthelyezés is történt. Egy alkalommal suparcondyler femur osteotomiát is végeztünk az említett két beavatkozással egy időben, illetve 3 alkalommal patella distalizáció is történt. A posztoperatív rehabilitációt, ha csak tehettük osztályunkon végeztettük, a posztoperatív 3. héttől gyógytornász vezetésével heti három alkalommal. Reluxatio egy alkalommal volt, egy értelmileg sérült fiatal nő, akinél a posztoperatív protokoll betartatása is nehézkes volt. Ezt az egy esetet leszámítva az összes betegnek megszúnt a ficamodása, reluxatio nem fordult elő. Ezen betegek mind az életminőségük szignifikáns javulásáról számoltak be (8). Ezt objektivizálandó jelenleg is retrospektív vizsgálat folyik, amelyre a Kujala féle patellofemoralis pontrendszert használjuk. Interneten keresztül kérdezzük ki a betegeket a mútét előtti, a posztoperatív fél-, egy-, illetve hároméves állapotukról. Akit tehetünk, behívunk kontroll röntgen elvégzésére, ahol a 30 fokos betekintő felvételen ellenőrizzük a patellofemoralis kongruenciát, a sulcus szöget, a lateralis trochlea magasságot, összehasonlítva a preoperatív mértekkel (8. ábra).

Bár ezen utánvizsgálat még nem zárult le és az adatok nagy része még beérkezésre, illetve feldolgozásra vár, de az eddigi eredmények alapján körvonalazódik a nemzetközi irodalom által leírt posztoperatív eredmény $(6,7)$.

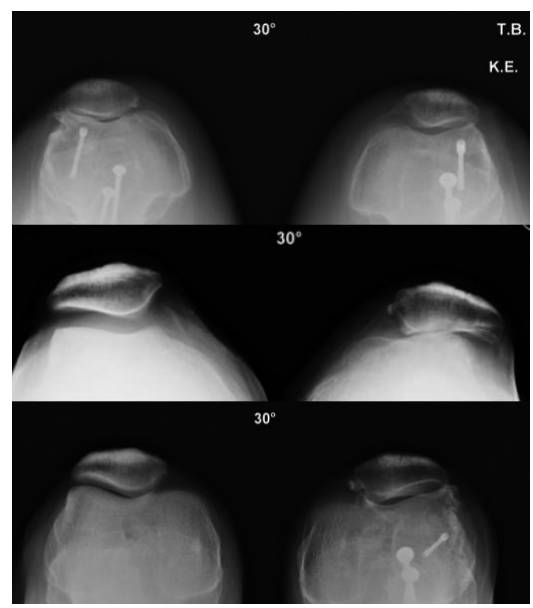

8. ábra

Felső kép: az 1. ábrán látható beteg posztoperativ 30 fokos betekintö röntgenfelvétele kétoldali Elmslie-Trillat, illetve lateralis trochlea kiemelést követöen.

Középső kép: egyoldali elégtelenül kezelt gyermekkori trauma talaján kialakult patella subluxatio 30 fokos betekintő röntgen.

Alsó kép: ugyanezen beteg posztoperativ képe lateralis trochleaszél kiemelést, illetve ventromedalizációt követően. 


\section{MEGBESZÉLÉS}

Ahogy már a bevezetésben is írtuk, a lateralis trochlea szél kiemelése a recidív patella ficamok kezelésében nem önálló beavatkozás. Csaknem minden esetben a húzási irány egyidejű korrekciójára is szükség van. Jelenleg a közlemények zöme inkább a medialis patellofemoralis ligamentum pótlás mellett teszi le a voksot. Véleményünk szerint a patellofemoralis ligamentum pótlás csak a normál vagy a normálhoz közelítő anatómiai viszonyok mellett hoz jó eredményt, ezért főleg az elégtelenül kezelt traumás ficamok esetén javasoljuk az elvégzést. Amennyiben congenitalis trochlea malformáció a luxatio egyik fő oka, álláspontunk szerint jobb eredményt érünk el ennek, illetve a húzási irány korrekciójával (9). Mint azt osztályunk anyaga is mutatja, megfelelő indikációval alkalmazva a térdkalács ficamok kezelésében a trochlea kiemelés egy ajánlott mútéti technika, amelylyel a betegek életminősége sokat javul és akár aktív sport tevékenységet is végezhetnek. Fontos hangsúlyozni, hogy ezen betegpopulációnál még a legjobban kivitelezett mútét mellett is javasoljuk évente egy alkalommal a kúraszerúen szedett per os chondroprotektív készítmények mellett intraartikuláris, nagy molekulasúlyú viscosupplementatiós készítmény beadását, amellyel a porckopás megelőzhető, illetve a progresszió lassítható (3).

\section{IRODALOM}

1. Cosgarea A. J., Schatzke M. D., Seth A. K., Litsky A. S.: Biomechanical analysis of flat and oblique tibial tubercle osteotomy for recurrent patellar instability. Am. J. Sports Med. 1999. 27. (4): $507-512$. https://doi.org/10.1177/03635465990270041601

2. Dejour D., Le Coultre B.: Osteotomies in patello-femoral instabilities. Sports Med. Arthrosc. Rev. 2007. 15. (1): 39-46. https://doi.org/10.1097/JSA.0b013e31803035ae

3. Farr S., Huyer D., Sadoghi P., Kaipel M., Grill F., Ganger R.: Prevalence of osteoarthritis and clinical results after the Elmslie-Trillat procedure: a retrospective long-term follow-up. Int. Orthop. 2014. 38. (1): 61-66. https://doi.org/10.1007/s00264-013-2083-2

4. Kapandji I. A.: Az ízületek élettana. 2. kötet. A térd. A patella mozgása. Budapest: Medicina. 2006. 108. p.

5. Merchant A. C., Fulkerson J. P., Leadbetter W.: The diagnosis and initial treatment of patellofemoral disorders. Am. J. Orthop. 2017. 46. (2): 68-75.

6. Neumann M. V., Stalder M., Schuster A. J.: Reconstructive surgery for patellofemoral joint incongruency. Knee Surg. Sports Traumatol. Arthrosc. 2016. 24. (3): 873-878. https://doi.org/10.1007/s00167-014-3397-3

7. Schöttle P. B., Fucentese S. F., Pfirrmann C., Bereiter H., Romero J.: Trochleaplasty for patellar instability due to trochlear dysplasia: A minimum 2-year clinical and radiological follow-up of 19 knees. Acta Orthop. 2005. 76. (5): 693-698. https://doi.org/10.1080/17453670510041781

8. van Sambeeck J. D. P., van de Groes S. A. W., Verdonschot N., Hannink G.: Trochleoplasty procedures show complication rates similar to other patellar-stabilizing procedures. Knee Surg. Sports Traumatol. Arthrosc. 2017. Dec. 5. [Epub ahead of print] https://doi.org/10.1007/s00167-017-4766-5

9. Weber A. E., Nathani A., Dines J. S., Allen A. A., Shubin-Stein B. E., Arendt E. A., Bedi A.: An algorithmic approach to the management of recurrent lateral patellar dislocation. J. Bone Joint Surg. Am. 2016. 98. (5): 417-427. https://doi.org/10.2106/JBJS.0.00354

\section{Dr. Vásárhelyi Gábor}

Uzsoki Kórház, Ortopéd-Traumatológiai Osztály

1145 Budapest, Uzsoki u. 29.

Tel.:06-1-4673700

vasarhelyigabor@hotmail.com 